Working Paper: 19/02. February 2019

Low cost airlines and international tourism demand. The case of Porto's airport in the northwest of the Iberian Peninsula

Marcos Álvarez-Díaz

Manuel González-Gómez

María Soledad Otero-Giráldez 


\title{
Low cost airlines and international tourism demand. The case of Porto's airport in the northwest of the Iberian Peninsula
}

\author{
Marcos Álvarez-Díaz ${ }^{\mathrm{b}}$, Manuel González-Gómez ${ }^{\mathrm{a} 1}$, María Soledad Otero-Giráldez ${ }^{\mathrm{a}}$ \\ ${ }^{a}$ Department of Applied Economics and Economic Modeling and Forecasting (EMAF) \\ research group, University of Vigo, Vigo, Spain. \\ ${ }^{b}$ Department of Economics and Economic Modeling and Forecasting (EMAF) research \\ group, University of Vigo, Vigo, Spain.
}

\begin{abstract}
It is widely argued that low-cost carriers (LCCs) lead to an increase in tourism demand. However, there is no conclusive evidence when the airport is located in a region with large diaspora and outbound tourism. To gain insight into the relationship between LCCs and international tourism demand, we analyse whether a causal relationship exists between the number of international LCC passengers at the Porto airport and international tourism demand in the Galicia-North Portugal Euroregion using a vector autoregressive model. We evaluate the dynamics of the impacts of the LCC passengers on international tourism demand in a tourism demand model framework. The number of low-cost international passengers has a positive influence on international tourism demand in the regions of North Portugal and Galicia (Spain). Furthermore, the confidence interval for estimated elasticity overlaps the values estimated for main tourism destinations in previous studies in the Iberian Peninsula.
\end{abstract}

Keywords: Low cost carriers, elasticity, Euroregion Galicia-North of Portugal, international tourism, cointegration.

\section{Introduction}

The liberalization process of air transport is the driving force of the passenger growth rate among LCCs (IATA, 2017, ICAO, 2016) as well as the main cause of an increased number of routes and reduced ticket prices (Halpern and Graham, 2015). Consequently, whereas LCCs transported 1 out of 5 passengers worldwide

\footnotetext{
1 *corresponding author: Manuel González-Gómez mgonzalez@uvigo.es http://emaf.webs.uvigo.es/
} 
ten years ago, that figure increased to 1 out of 4 passengers last year. LCCs show the highest market share in Europe with 1 out of 3 passengers. Market penetration of LCCs in the Iberian Peninsula is higher than the European average (TURSPAIN; ANAC, 2018). It reached 57\% in April 2018 of the international arrivals to Spanish airports (TURSPAIN). Continental Portuguese airports show similar figures, with the exception of Lisbon, where such figures are lower (ANAC, 2018). The relatively short distances between some airports in Spain and Portugal may lead people to choose neighbouring countries' airports when they decide to travel. This is the case in the region of Galicia and its largest city, which are approximately 100 and 150 $\mathrm{km}$ away away from the Porto airport, respectively. About 2.7 million inhabitants have three airports available in Galicia (Spain). The airports have scheduled mostly domestic connections that transported about 4.5 million passengers in 2016. North Portugal has 3.9 million inhabitants and one airport (Porto) that transported over 10 million passengers in 2016, of which 3.0 million were international low-cost passengers. The development at Porto started in 2005 and did not have any experience with charter flights. Public subsidies to the airport and public aid to the LCCs have played a major role (ANA, 2000; ANA, 2007) in the evolution of the number of passengers and have generated a social and academic debate concerning the effects of LCCs. 


\section{Illustration 1: The Regions of North Portugal and Galicia (Spain)}

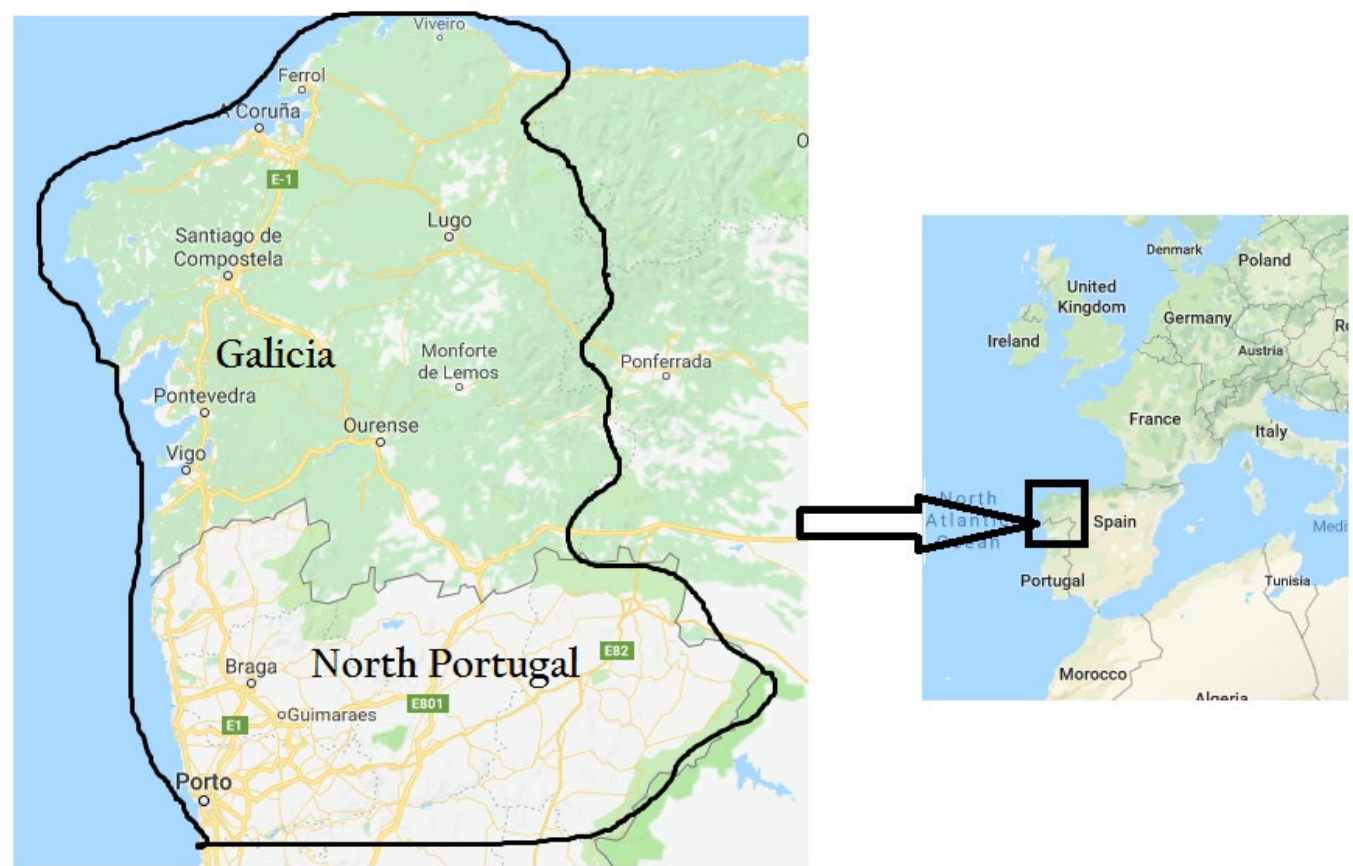

Source: https://www.google.com/maps/@41.1153969,-8.0160115,9.93z?hl=en

Because the attraction of tourists relies on the existence of transportation at the right price (Martin-Cejas, 2010; Halpern and Graham, 2015; Lohmann et al, 2009), authorities have subsidized the development of airport facilities (ANA, 2000; ANA, 2007; Graham and Shaw, 2008), airport/marketing fees (Graham and Dennis, 2010) and/or liberalization of the air market (Dobruszkes and Mondou, 2013; Alsumairi and Tsui, 2017) to increase injections of money into the economy in the form of tourism spending. ${ }^{2}$ Researchers have reached a consensus that the impact on the tourism industry varies based on the destination's touristic importance. On one hand, the development in the number of air travellers can be the result of tourist's visiting the airport's region of influence (inbound tourism). Many authors have reported an increase in international and domestic tourist flows as a consequence of

\footnotetext{
${ }^{2}$ Eugenio-Martin and Inchauste-Sintes (2016) have reported one additional source of injections without increasing the number of air passengers, namely that some visitors to the Canary Islands increased their expenditures at the destination as a consequence of the savings resulting from the cheaper fares offered by LCCs.
} 
the increasing share of LCCs, including Donzelli (2010), Graham and Dennis (2010), Aguiló et al. (2007), Rey et al. (2011) and Alsumairi and Tsui (2017), who found positive effects of LCCs on international tourism arrivals; Chung and Whang (2011) and Tsui (2017) found the same effect on domestic visitor arrivals.

On the other hand, passengers do not only arrive for vacation or business; passengers visiting friend and relatives (VFRs) are also considered tourists (Graham and Dennis, 2010). However, VFRs usually do not generate spending in the local economy, making only small injections into the circular flow of income. Furthermore, the number of passengers is also affected by the residents in the airport's area of influence who are visiting other destinations (outbound tourism). Instead of serving as an injection of money, outbound tourism withdraws money from the circular flow of income. Dobruszkes and Mondou (2013) and Hazledine and Collins (2011) analyse examples with large diasporas and conclude that in such cases, injections are smaller (leakages larger) due to VFR. As a consequence, in many cases, VFRs, student mobility and outbound tourism are the driving forces behind low-cost flights (Dobruszkes and Mondou, 2013; Dobruszkes, 2013; Castillo, Manzano and Marchena Gómez, 2010; O'Connell and Williams, 2005; Graham and Shaw, 2008; Davidson and Ryley, 2010).

Therefore, no conclusive evidence in the empirical literature shows that the increase in the number of air passengers generates greater injections into the circular flow of income. Moreover, the larger the diaspora, the more likely it is that the share of VFRs in the number of LCC passengers is higher and that the income injections are smaller. Finally, higher outbound tourism results in larger leakages. Consequently, instead of the planned injections by the authorities when they decide to attract LCC passengers, a high share of VFRs in inbound tourism and a high proportion of outbound tourism in the total number of air passengers can lead to a net withdrawal of money from the circular flow of income.

North Portugal and Galicia have sizeable diaspora populations living abroad. Approximately 1.7 million nationals from Portugal and 0.5 million from Galicia live 
abroad. Most of them live in Central and Northern Europe (Belgium, France, the Netherlands, Germany, Luxemburg, Switzerland and the UK), which are the major Iberian Peninsula international tourism source markets and LCC routes from Porto's airport. Along with the growth in the number of international passengers, North Portugal doubled its number of international tourists from 2005 to 2016. The neighbouring Spanish region of Galicia only experienced a $16 \%$ increase in the same period. Moreover, the share of international tourism increased from one-third in 2005 to more than half in 2016 in North Portugal.

Both regions had an income per capita below the EU average and an unemployment rate above the EU average, and international tourism demand can be a driving force of GDP growth and new jobs. Due to the long distances to most of the tourist source markets, mainly in Central and Northern Europe, international tourism demand benefited from reduced cost of travel and an increased number of routes. Better understanding of the impact of LCCs and tourism routes can be of great assistance in planning development strategies in the tourism industry and airport management, specifically the role of the LCCs not only in north Portugal and Galicia (Spain) but also in other regions.

The causal relationship between the number of international passengers and international leisure tourism (excluding VFRs) could suggest that the measures to promote airport passengers have effectively increased the number of international tourists. The region's attractiveness together with the new routes and/or low fares has contributed to the rise in the number of international leisure tourists. On the contrary, no causality between the number of international LCC passengers and international tourism could result from the region's lack of attractiveness where the airport is located and more importance of the airport in terms of outbound tourism and/or VFRs than international leisure tourism.

In our paper, we estimate the effects of the number of international LCC passengers that arrive at Porto's airport on international tourism demand in North Portugal in a 
tourism demand model framework. To the author's knowledge, this is the first empirical study that analyses the effects of international passengers on international tourism demand in a region that is not a main tourist destination and has undergone a large diaspora. Furthermore, our study extends the quantification of the effects of the existence of LCCs in Porto (Portugal) on the international tourism demand in the neighbouring region of Galicia (Spain). The remainder of this paper is organized as follows: next section describes the data and techniques used to quantify the effects of LCC passengers on tourism demand, the results and discussion section presents the findings and the concluding remarks complete the paper. 


\section{Materials and methods}

\subsection{Materials}

Various variables describe the temporal evolution of international tourism demand, such as international tourism revenues, number of tourist arrivals and overnight stays. No time series is available for monthly tourism revenues. Aguiló et al. (2007) and Halpern and Graham (2015), among other authors, reported a decrease in the length of stay simultaneously with an increase in the number of arrivals and market share of LCCs. Considering that the number of arrivals would overvalue the increase in tourism demand, overnight stays takes into account the duration of the stay (Garin Muñoz, 2009) and can be considered a better proxy for tourism demand in our study.

Table 1: Descriptive statistics

\begin{tabular}{|l|l|l|l|l|l|l|}
\hline & TOURISMP & TOURISMG & IPI & PG & PP & PASSENGERS \\
\hline Mean & $186,319.5$ & 119,141 & 101.4 & 101.3 & 101.6 & $118,836.8$ \\
\hline Median & $162,961.5$ & 112,623 & 101.7 & 101.5 & 101.1 & 108,754 \\
\hline Maximum & 516,823 & 294,556 & 119.2 & 103.5 & 104.9 & 318,010 \\
\hline Minimum & 49,200 & 35,909 & 79.2 & 98.1 & 98.7 & 7,027 \\
\hline Std. dev. & $97,746.5$ & $66,598.6$ & 7.7 & 1.07 & 1.68 & $75,329.5$ \\
\hline
\end{tabular}

The variable TOURISMP measures the number of tourist nights international guests spend in the North Portugal region, and TOURISMG represents the number of nights tourists spend in the Galicia region. The data used were obtained from the Portuguese Statistical Institute and the Spanish Statistical Institute. Previous research on tourism demand and economic theory considers price level and income the main explanatory variables in tourism demand. Therefore, PP and PG, which represent the price level (measured as Consumer Price Index-CPI) for North Portugal and Galicia, respectively, are included in the analysis. The indexes were also obtained from the Portuguese Statistical Institute and the Spanish Statistical Institute. The variable IPI represents the main source markets of international tourism to North Portugal and Galicia (Industrial Production Index in the EU member States) and is also included as a 
measurement of income. Gross domestic product (GDP) or personal disposable income (PDI) are probably better indicators of income, but we could not use them because of the lack of these variables at a monthly frequency. Data were downloaded from the EU Statistical Office (Eurostat). The other variable included in the analysis is the number of international air passengers flying with LCCs at the Porto airport (PASSENGERS). Porto's airport authority provides the data. The variables TOURISMP, TOURISMG, IPI and PASSENGERS time series were seasonally adjusted, and all variables were logtransformed to interpret elasticities. The sample period extended from January 2005 to December 2016.

\subsection{Methods}

To check for the existence of a statistical long-run relationship between the LCCs and international tourism demand, we define the international tourism demand for North Portugal (equation 1) and for Galicia-Spain (equation 2) separately:

TOURISMP $P_{\mathrm{t}}=\beta_{0}+\beta_{1} \cdot I P I_{\mathrm{t}}+\beta_{2} \cdot \mathrm{PP}_{\mathrm{t}}+\beta_{3} \cdot$ PASSENGERS $\mathrm{t}_{\mathrm{t}}+v_{\mathrm{t}}$

TOURISMG $G_{\mathrm{t}}=\beta_{0}+\beta_{1} \cdot$ IPI $_{\mathrm{t}}+\beta_{2} \cdot \mathrm{PG}_{\mathrm{t}}+\beta_{3} \cdot P A S S E N G E R S_{\mathrm{t}}+v_{\mathrm{t}}$

where $v_{\mathrm{t}}$ is the disturbance term. The estimation of the demand that allows us to calculate the effects of international passengers on LCCs at the Porto airport on international tourism in the Galicia-North Portugal Euroregion is based on Engle and Granger's (1987) work. Once we have checked that all time series included in (1) and (2) are integrated of the same order, we determine whether the variables are cointegrated using complementary cointegration tests from three sets of authors, Engle and Granger (1987), Phillips and Ouliaris (1990), and Johansen and Juselius (1990). They involve testing the existence of a long-run equilibrium relationship between the variables included in equation (1) for North Portugal and equation (2) for Galicia. We also estimate the confidence intervals for the explanatory variables' effects. 
Once we have proven the existence of a relationship between our variables, we estimate the error correction model (ECM) represented in equation (3) for North Portugal and (4) Galicia.

$$
\begin{aligned}
& \Delta \text { TOURISMP }_{t}=\gamma_{0}+\sum_{i=1}^{p-1} \gamma_{i} \cdot \Delta \text { TOURISMP }_{t-i}+\sum_{i=1}^{p-1} \mu_{j} \cdot \Delta I P I_{t-j}+\sum_{i=1}^{p-1} \delta_{j} \cdot \Delta P P_{t-j}+\sum_{i=1}^{p-1} \lambda_{j} \cdot \Delta \text { PASSENGERS } \\
& t-j \\
& \text { TTOURISMG }_{t}=\gamma_{0}+\sum_{i=1}^{p-1} \gamma_{i} \cdot \Delta \text { RISIS }+\phi \cdot \hat{v}_{t-1}+\varepsilon_{t} \text { (3) }
\end{aligned}
$$

where $\varepsilon_{t}$ is assumed to be a white-noise error term, $\hat{v}_{t-1}$ is the error correction term $(\mathrm{ECT})^{3}$ and CRISIS is a dummy variable that takes a value of 1 during the financial global crisis and the European debt crisis in the EU member states. The rest of the variables were defined in subsection 2.1 .

\section{Results and discussion}

The analysis of the existence of a statistical long-run relationship between the variables included in the demand functions (1) (2) begins with us checking the time series' cointegration property. Table 2 shows the results of the Dickey and Fuller (1981) test. All six time series are non-stationary in levels, but they are stationary after the first differentiation, i.e. integration of order one. Therefore, it is possible to apply multiple cointegration tests: the Johansen Cointegration test to determine the number of cointegration vectors (Johansen and Juselius, 1990), the Phillips-Ouliaris Test (Phillips and Ouliaris, 1990) and the Engle and Granger Test (Engle and Granger, 1987).

\footnotetext{
${ }^{3}$ The coefficient of ECT describes the speed of the adjustment back from any deviation from the long-term equilibrium. This coefficient must be statistically significant to corroborate the existence of cointegration.
} 
Table 2. Dickey and Fuller test for unit root

\begin{tabular}{cc}
\hline Ho: variable has a unit root & t-statistic \\
\hline TOURISMG & $1.40(2)$ \\
TOURISMP & $2.65(2)$ \\
PASSENGERS & $3.99(0)$ \\
IPI & $0.04(3)$ \\
PG & $-0.84(12)$ \\
PP & $-0.85(12)$ \\
$\Delta$ TOURISMG & $-11.04^{*}(1)$ \\
$\Delta$ TOURISMP & $-13.28^{*}(1)$ \\
$\Delta$ PASSENGERS & $-2.70^{*}(4)$ \\
$\Delta$ IPI & $-3.97 *(2)$ \\
$\Delta$ PG & $-2.91 *(11)$ \\
$\Delta$ PP & $-1.87^{* *}(11)$ \\
\hline
\end{tabular}

Note: $\Delta$ is the first difference operator. Values in parenthesis specify the lag length based on Schwarz Information Criterion.* indicates significance at $5 \%$ level. $* *$ indicates significance at $10 \%$ level. Critical values are based on MacKinnon (1996).

Table 3 shows the results of the three cointegration tests used in our study. The trace and max eigenvalue of Johansen and Juselius's cointegration test indicate one cointegration vector at 5\%. All the tests reject the null hypothesis of no cointegration at the level of significance of $5 \%$. This result confirms the presence of a long-run relationship between international tourism to North Portugal and the explanatory variables considered in equation (1) as well as international tourism to Galicia and the explanatory variables included in equation (2).

Table 3: Results of the different cointegration test

\begin{tabular}{c|cc}
\hline Cointegration Test & Statistic(Galicia) & Statistic(Portugal) \\
\hline Engle and Granger & $\mathrm{Tau}=-5.39^{*}$ & $\mathrm{Tau}=-4.86^{*}$ \\
(1987) & $\mathrm{Z}=-48.15^{*}$ & $\mathrm{Z}=-49.65^{*}$ \\
\hline Phillips and Ouliaris & $\mathrm{Tau}=-5.39^{*}$ & $\mathrm{Tau}=-9.07^{*}$ \\
$(\mathbf{1 9 9 0 )}$ & $\mathrm{Z}=-47.69^{*}$ & $\mathrm{Z}=-120.47^{*}$ \\
\hline \multirow{3}{*}{ Johansen and } & $\mathrm{r}=0 ;$ Trace $=63.87^{*}$ & $\mathrm{r}=0 ;$ Trace $=72.71^{*}$ \\
Juselius (1990) & $\mathrm{r}=1$; Trace $=42.91$ & $\mathrm{r}=1$; Trace $=30.07$ \\
\cline { 2 - 3 } & $\mathrm{r}=0 ;$ Eigenvalue $=61.68^{*}$ & $\mathrm{r}=0$; Eigenvalue $=42.64^{*}$ \\
& $\mathrm{r}=1$; Eigenvalue $=20.29$ & $\mathrm{r}=1$; Eigenvalue $=17.19$ \\
\hline
\end{tabular}

Note: P-values from Mackinnon (1996) and Mackinnon-Haug-Michelis(1999). $(*)$ denotes rejection of the hypothesis of "no cointegration" at the 0.05 level

The results are in line with literature that showed an increase in tourism flows as a consequence of the increase in the number of LCC passengers (Donzelli, 2010; Graham and Dennis, 2010; Aguiló et al., 2007; Rey et al., 2011; Alsumairi and Tsui, 2017; Chung 
and Whang, 2011, and Tsui, 2017). However, those previous empirical studies concerned major tourism destinations rather than airports in regions that are not major international tourism destination and that have undergone large diasporas, i.e. a high share of VFR tourism (Dobruszkes, 2013; Dobruszkes and Mondou, 2013; Hazledine and Collins, 2011; O'Connell and Williams, 2005). Furthermore, our study also extends the analysis to examine the effects of international passengers on international inbound tourism to Galicia, a region of the neighbouring country of Spain. The results show a positive effect of LCCs at the Porto airport (Portugal) that goes beyond the country's borders. It positively affects the international tourism demand in the neighbouring Spanish region of Galicia with a large number of airports per capita but only a few international flights scheduled during the period of study.

We can confirm an increase in spending in the economy caused by the higher number of nights that international tourists stay in hotels and similar establishments in the North Portugal and Galicia regions (Spain). This increase implies an injection of money into the circular flow of income in both regions that was caused by the rise in the number of international LCC passengers to the Porto airport.

The next step is to estimate the ECM (equations 3 and 4) associated with the models represented in equations 1 and 2 for North Portugal and Galicia, respectively. It allows us to quantify the impact of each of the variables include in the ECM. 
Table 4: Long and short run estimation

\begin{tabular}{|c|c|c|c|c|c|}
\hline \multicolumn{4}{|c|}{ North Portugal } & \multicolumn{2}{|l|}{ Galicia } \\
\hline \multicolumn{6}{|c|}{ Long-run equation } \\
\hline Variable & Coefficient & p-value & $\begin{array}{c}\text { Bootstrap } \\
\text { interval } \\
\text { estimation }\end{array}$ & Coefficient p-value & $\begin{array}{c}\text { Bootstrap } \\
\text { interval } \\
\text { estimation }\end{array}$ \\
\hline Intercept & 33.17 & 0.00 & & 0.00 & \\
\hline PASSENGER & 0.24 & 0.00 & $(0.19,0.29)$ & 0.00 & $(0.12,0.16)$ \\
\hline IPI & 2.33 & 0.00 & $(1.54,3.11)$ & 0.00 & $(1.36,2.0)$ \\
\hline PP & -7.49 & 0.00 & $(-10.8,-4.1)$ & - & - \\
\hline PG & - & - & & -5.33 & $(-6.9,-3.8)$ \\
\hline \multicolumn{6}{|c|}{ Short-run equation } \\
\hline Varia & & Coefficien 1 & p-value & Coefficien 1 & p-value \\
\hline Interc & & 0.02 & 0.02 & 0.01 & 0.06 \\
\hline & ECT & -0.13 & 0.02 & -0.25 & 0.00 \\
\hline D(PASSEN & NGERS) & 0.31 & 0.00 & 0.19 & 0.01 \\
\hline D(TOURIS & $\mathrm{MP}(-1))$ & -0.39 & 0.00 & - & - \\
\hline D(TOURISI & MP(-12)) & -0.11 & 0.09 & - & - \\
\hline D(TOURIS & $\mathrm{MG}(-1))$ & - & - & -0.18 & 0.02 \\
\hline D(TOURIS & $M G(-7))$ & - & - & -0.16 & 0.02 \\
\hline & Crisis & -0.03 & 0.03 & -0.02 & 0.01 \\
\hline \multicolumn{6}{|c|}{ Diagnosis tests } \\
\hline & & & p-value & & p-value \\
\hline & & $\mathrm{Q}(1)$ & 0.28 & & 0.73 \\
\hline Autocorrela & ation & jung-Box-Q & & & \\
\hline & & $\mathrm{Q}(12)$ & 0.27 & & 0.17 \\
\hline Heterosked & lasticity & White test & 0.79 & & 0.17 \\
\hline Misspecific & cation & ESET test & 0.12 & & 0.10 \\
\hline
\end{tabular}

As we can see in table 4, the estimated coefficient associated with the ECT is in both cases statistically significant and corroborates the existence of cointegration between our variables. All estimates have the expected signs and are statistically significant. According to these findings, we can confirm that if the LCC increases by $1 \%$, the demand will increase by $0.24 \%$ and $0.13 \%$ in North Portugal and Galicia, respectively. The bootstrap confidence intervals are $(0.19,0.29)$ for North Portugal and $(0.12,0.16)$ for Galicia. Income elasticity is approximately $2.33 \%$ in North Portugal (bootstrap confidence intervals: $(1.54,3.11)$ ) and $1.69 \%$ in Galicia (bootstrap confidence interval: $(1.36,2.0)$ ), i.e. high income elasticity that is in line with previous elasticity estimates for international tourism demand to Spain (Rey at al., 2011; Alvarez-Diaz at al., 2015) and international tourism demand to Portugal (Daniel and Ramos, 2002).

The price elasticity indicates that a $1 \%$ price increase in north Portugal or Galicia reduces tourism demand by $7.49 \%$ and $5.33 \%$, respectively, which can be considered high and 
reflect the strong influence of price on demand in both regions. The bootstrap confidence intervals are $(-10.8,-4.1)$ for North Portugal and $(-6.9,-3.8)$ for Galicia. Crouch (1995) reported higher price elasticities when the length of stay is taken as a measure of demand as is the case when we consider the number of arrivals (number of tourists). Moreover, Crouch (1995) also found that price elasticity of travel to Northern Europe is significantly lower than that for Southern Europe/Mediterranean destinations, i.e. southern destinations are more price sensitive. Government agencies, the industry and the airport authorities should be aware of these competitive factors. High price elasticity has been reported in previous studies for Spain (Garín-Muñoz, 2006; Garín-Muñoz and Montero-Martín, 2007) and Portugal (Daniel and Ramos, 2002). For instance, in the 1990s, demand fell strongly in Portugal as a consequence of price increases (Smith and Jennifer, 1998). The bootstrap confidence interval of price elasticity and bootstrap confidence interval of income elasticity for the Galicia region overlap each confidence interval for North Portugal. These results confirm our expectations that income elasticity and price elasticity are not statistically different for Galicia and North Portugal because both regions attract similar tourists. On the other hand, most of the tourist attractions (towns; cities; and other historical, cultural and natural sites) of North Portugal are closer to Porto's airport than tourist attractions of Galicia. It implies that confidence intervals of LCC international passengers demand that elasticities for both regions do not overlap each other. Consequently, the effects of international passengers arriving at Porto's airport for international tourism are statistically higher in North Portugal than in Galicia.

Table 4 also provides the estimated coefficient of the ECM. The LCCs' impact also turns out to be positive and significant in the short term with an elasticity of 0.31 for North Portugal and 0.19 for Galicia. Moreover, international tourism demand is elastic as it is based on the previous period's tourism level. The ECT illustrates that the speed of adjustment back from the long-term equilibrium is faster in Galicia (0.25) than in Portugal (0.15), which can be interpreted as a higher correction of the deviation caused by the longterm equilibrium by an external shock. In addition to the estimated coefficients, table 4 also provides the results of diagnostic tests commonly used in the literature to detect problems of serial correlation and heteroskedasticity. Additionally, the presence of misspecification problems was checked by using Ramsey's reset test. These tests allow us to validate the consistency and robustness of the results of the estimation process 
Table 5. Summary of the estimated effects of international LCC passengers (based on the mean values of the series).

\begin{tabular}{|c|c|}
\hline North Portugal & Galicia \\
\hline \multicolumn{2}{|c|}{ A: 1\% international passenger increase at Porto's airport $=1188$ passengers } \\
\hline $\begin{array}{c}B_{1}: \frac{0.19 \%, 0.29 \% \text { nights increase caused by }}{\text { the } 1 \% \text { international passenger growth }} \\
=\text { between } 394 \text { and } 540 \text { nights }\end{array}$ & $\begin{array}{c}B_{2}: \frac{0.12 \%, 0.16 \% \text { nights increase caused by }}{\text { the } 1 \% \text { international passenger growth }} \\
=\text { between } 143 \text { and } 191 \text { nights }\end{array}$ \\
\hline \multicolumn{2}{|c|}{ Additional LCCS-international passengers needed to get one additional night booked } \\
\hline $\mathbf{C}_{1}=\mathrm{A} / \mathrm{B}_{1}=$ between 2.2 and 3 passengers & $\mathbf{C}_{2}=\mathrm{A} / \mathrm{B}_{2}=$ between 6.2 and 8.3 passengers \\
\hline \multicolumn{2}{|c|}{ International tourism expenditure per day (night) } \\
\hline $\mathbf{D}_{1}=76.5 €$ & $\mathbf{D}_{2}=103 €$ \\
\hline \multicolumn{2}{|c|}{ International tourism expenditure increase per additional international LCC passenger } \\
\hline$=\mathrm{D}_{1} / \mathrm{C}_{1}=$ between $25.5 €$ and $34.8 €$ & $=\mathrm{D}_{2} / \mathrm{C}_{2}=$ between $12.4 €$ and $16.6 €$ \\
\hline \multicolumn{2}{|c|}{ Total mean injection of money per month } \\
\hline Between 3 million $€$ and 4.1 million $€$ & Between 1.4 million $€$ and 2 million $€$ \\
\hline
\end{tabular}

Source: Own calculations based on computed bootstrap confidence intervals (table 4), mean values (table 1), Portuguese Statistical Office (INE, 2017) and Spanish Statistical Office (INE).

To easily appreciate the injections of money into the economy, we calculate in table 5 the international tourism expenditure increase in both regions caused by each additional international LCCS passenger that arrives at Porto's airport. We take mean values of the period of analysis. According to the computed confidence intervals, a 1\% rise in the number of international passengers (1188 passengers per month) will lead to an increase of between 394 and 540 in the number of nights spent by international tourists in North Portugal and between 143 and 191 in Galicia. Consequently, between 2.2 and 3.0 new passengers to North Portugal and between 6.2 and 8.3 to Galicia are needed for one additional night. According to the National Statistical Offices of Portugal (INE, 2017) and Spain (INE), the daily average international tourist expenditure in 2016 was $76.5 €$ in Portugal and $103 €$ in Galicia, which means that on average, each international passenger arriving at Porto's airport increases the international tourist expenditure by between $25.5 €$ and $34.8 €$ in North Portugal and between 12.4 and 16.6 in Galicia. The average monthly injections of money into the circular flow of income caused by international passengers to Porto's airport are approximately between 3 and 4.1 million euro for North Portugal and between 1.4 and 2 million for the neighbouring region of Galicia. 


\section{Conclusions}

Change in terms of higher market share of LCCs is a fact in many airports, and this is also the case in the Porto airport, where LCCs have played a key role in the increase in the number of passengers. Even though various authors have reported the non-contribution of passengers to vacation and business tourism in areas with large diasporas and outbound tourism, other studies have shown a positive effect of LCC passengers on tourism demand. Consequently, the uncertain effects of subsidizing LCCs and airport facilities to increase the number of international tourists in a region (North Portugal) that was not a traditional tourism destination and has undergone a large diaspora is remarkable.

Due to the proximity of the Spanish region of Galicia, specifically its major city (Vigo), the analysis of the effects of LCCs on international tourism demand in North Portugal has been extended to the arrival of international tourism to Galicia (Spain).

Simultaneously with the increasing number of international arrivals at the Porto airport, in the of North Portugal region, where the airport is located, international tourism doubled from approximately 600 thousand tourists in 2005, when LCCs started operating in Porto, to 1.2 million international visitors in 2016. The neighbouring Spanish region of Galicia showed an increase in the number of international tourists from 600 thousand in 2005 to nearly 700 thousand in 2016.

The empirical analysis confirms that the estimations of international tourism demand for North Portugal and Galicia show similar results for both regions: Income elasticities suggest a rise in the number of nights spent in expansion periods and a drop in tourism demand as a response to lower economic growth rates in the EU member states that are the main source markets for both regions. Tourism demand is very sensitive to price changes in both regions. Southern European countries usually show higher international tourism price elasticities than Northern European countries, which is a warning to the tourism sector and airport management. The computed bootstrap confidence interval for price elasticity and income elasticity in both regions overlap and show that the elasticities are statistically non-different in both regions, i.e. both regions attract international tourists that react similarly to income and price changes. 
On the contrary, the fact that bootstrap confidence intervals for the reaction of international tourism on international passengers at the Porto airport do not overlap each other confirm the expected statistically different effects in North Portugal and Galicia. The number of nights spent by international tourists turns out to be elastic based on changes in the number of international passengers. However, a $1 \%$ increase in the number of international passengers arriving at the Porto airport causes a rise in international tourism demand of $0.24 \%$ in North Portugal but only of $0.13 \%$ in Galicia, which implies an injection of money into the circular flow of income in both regions that can easily be appreciated by the calculated rise in international tourist expenditure per additional LCC passenger arriving at Porto's airport: between 25.5 and $34.8 €$ in North Portugal and 12.4 and $16.6 €$ in Galicia or, by the monthly average money injection to the circular flow of income, between 3 and 4.1 million $€$ for North Portugal and between 1.4 and 2 million for the neighbouring region of Galicia.

\section{Acknowledgements}

MGG thanks the sabbatical year granted by his employer, which gave him the opportunity to devote full time to research. He also acknowledges financial support from IACOBUS (Euroregion Galicia-North Portugal) and the Airport of Porto for the facility to access data used in this study.

\section{References}

Aguiló , E., Rey, B., Roselló, J. and Torres C.M. (2007). The Impact of the PostLiberalisation Growth of LCCs on the Tourism Trends in Spain Rivista di Politica Economica, SIPI Spa, vol. 97(1), 39-60.

Alsumari, M. and Tsui K. W. H. (2017) A case study: The impact of low-cost carriers on inbound tourism of Saudi Arabia. J. Air Transp. Manag. 62, 129-145.

Álvarez-Díaz, M., González-Gómez, M. and Otero-Giráldez, Mª S. (2015). Estimating Price and Income Demand Elasticities for Spain Separately by the Major Source Market. Tourism Economics, 21(5), 1103-1110

ANA. 2000. Plano Diretor Aeroporto Francisco Sá Carneiro 2000. Lisboa: ANA Aeroportos de Portugal.

ANA. 2007. Plano Diretor Aeroporto Francisco Sá Carneiro 2007. Lisboa: ANA Aeroportos de Portugal. 
ANAC (2018) Boletim Estatistico trimestral no 36. Março 2018

Chung J. Y. and Whang, T. (2011) The impact of low cost carriers on Korean Island tourism. Journal of Transport Geography, 19. 1335-1340.

Crouch GI (1995) A meta-analysis of tourism demand. Annals of Tourism Research 22(1): 103-118.

Daniel A. C. M. and Ramos F. F. R. (2002) Modelling inbound international tourism demand to Portugal. International Journal of Tourism Research, 4 , 193-209

Davison, L. an Ryley, T. (2010). Tourism destination preferences of low-cost airline users in the East Midlands. Journal of Transport Geography, 18(3), 458-465.

Dickey, A.D. and Fuller, W.A., 1981. Likelihood ratio statistics for autoregressive time series with a unit root. Econometrica 49, 1057-1072.

Dobruszkes, F. (2013). The geography of European low-cost airline networks: a contemporary analysis. Journal of Transport Geography, 28, 75-88.

Dobruszkes F., Mondou V. (2013), Aviation liberalization as a means to promote international tourism: The EU-Morocco case. J. Air Transp. Manag 29, 23-34.

Donzelli, M. (2010) The effect of low-cost air transportation on the local economy: evidence from Southern Italy. J. Air Transp. Manag. 16 (3), 121e126.

Engle R.F. and Granger C.W.J. (1987). Cointegration and Error Correction: Representation, Estimation and Testing. Econometrica 55, 251-76.

Eugenio-Martin, J. L. and Inchauste-Sintes, F. (2016) Low-cost travel and tourism expenditures. Annals of Tourism Research, 57, 140-159.

Garín-Muñoz. T, (2006) Inbound International Tourism to Canary Island: a dynamic panel data model. Tourism Management 27(1):281-191.

Garín-Muñoz. T. (2009) Garín-Muñoz, T. (2009). Tourism in Galicia: domestic and foreign demand. Tourism Economics, 15(4), 753-769.

Garín-Muñoz, T. and Montero-Martín, LF. (2007) Tourism in the Balearic Island: a dynamic model for International demand using panel data. Tourism Management 28: 1224-1235.

Graham, A. and Shaw, J. (2008), "Low-cost airlines in Europe: Reconciling liberalization and sustainability", Geoforum, 39

Graham, A. and Dennis, N. 2010. The impact of low cost airline operations to Malta. J. Air Transp. Manag., 16(3), 127-136.

Graham, A. 2013. Understanding the low cost carrier and airport relationship: A critical analysis of the salient issues. Tourism Management, 36, 66-76. 
Granger, C.W..J. 1988. Some Recent Developments in a Concept of Causality, Journal of Econometrics, 39, 199-211.

Halpern, N. and Graham, A. (2015) Airport route development: a survey of current practice. University of Westminster. Westminster Research.

http://www.westminster.ac.uk/westminsterresearch.

Hazledine, T and Collins, S. (2011) Paying the pilot? The economics of subsidising international air travel to small remote island nations with large diaspora. J. Air Transp. Manag., 17, 187-194.

IATA (2017) Aviation Benefits 2017. https://www.iata.org/policy/Documents/aviationbenefits- $\% 20$ web.pdf

ICAO (2016) Air transport liberalization and economic development of the countries.

Working paper A39-WP/189 EC/20 11/8/16.

https://www.icao.int/Meetings/a39/Documents/WP/wp_189_en.pdf

INE (2017) Estatísticas de turismo-2016. Instituto Nacional de Estatística.

https://www.ine.pt/xportal/xmain?xpid=INE\&xpgid=ine_publicacoes\&PUBLICACOESp $\underline{\mathrm{ub} \text { boui }=277048338 \& \text { PUBLICACOEStema }=55581 \& \text { PUBLICACOESmodo }=2}$

INE. Average daily expenditure by international tourist by main Autonomous

Community of destination. Tourist Expenditure Survey. Egatur.

http://ine.es/jaxiT3/Tabla.htm?t=10839\&L=1

Johansen, S. y Juselius, K. (1990). "Maximun Likelihood Estimation and Inference on Cointegration with Applications to the Demand for Money". Oxford Bulletin of Economics and Statistics, vol. 52, pp. 169-210.

Lohmann, G., Albers, S., Koch, B., Pavlovich, K., 2009. From hub to tourist destinatione An explorative study of Singapore and Dubai's aviation-based ransformation. J. Air Transp. Manag. 15 (5), 205e211.

MacKinnon, J.G. (1996). Numerical distribution functions for unit root and cointegration tests. Journal of Applied Econometrics, 11(6), 601-618.

MacKinnon, J.G., Haug, A. A. and Michelis, L. (1999). Numerical distribution functions of likelihood ratio tests for cointegration. Journal of applied Econometrics, 14(5), 563577.

Martín-Cejas, R.R. (2010). Ramsey pricing including CO2 emission cost: An application to Spanish airports. J. Air Transp. Manag. 16(1), 45-47.

Paulina, M., and Cortés-Jiménez, I. (2010). Have low-cost carriers influenced tourism demand and supply? The case of Alghero, Italy. Tourism Analysis, 15, 617-635.

Phillips, P. C., and Ouliaris, S. 1990. Asymptotic properties of residual based tests for cointegration. Econometrica, Journal of the Econometric Society, 58,1, 165-193. 
O'Connell, J. and Williams, G. 2005. Passenger's perceptions of low cost airlines and full service carriers: a case study involving Ryanair, Aer Lingus, Air Asia and malasia Airlines. J. Air Transp. Manag. 11 (4), 259-272.

Rey, B., Myro, R.L., Galera, A., 2011. Effect of low-cost airlines on tourism in Spain. A dynamic panel data model. J. Air Transp. Manag. 17 (3), 163-167.

Ryanair (2018). Map of routes. Retrieved from http://www.ryanair.com/es/destinos$\underline{\text { economicos }}$

Smith, C. and Jennifer, P. (1998) International tourism reports. Travel and tourism intelligence, 1, 47-66.

Tsui, K.W.H. 2017. Does a low-sot carrier lead the domestic tourism demand and growth of New Zealand?. Tourism Management, 60 390-403.

TURSPAIN. http://estadisticas.tourspain.es/es-

es/estadisticas/otrasestadisticas/companiabajocoste/paginas/default.aspx 